\title{
A contribution to understanding the complex nature of peisleyite
}

\author{
S. J. Mills ${ }^{1} *$, C. $\mathrm{MA}^{2}$ AND W. D. BirCH ${ }^{1}$ \\ 1 Geosciences, Museum Victoria, GPO Box 666, Melbourne 3001, Victoria, Australia \\ 2 Division of Geological and Planetary Sciences, California Institute of Technology, Pasadena, California 91125, \\ USA
}

[Received 03 August 2011; Accepted 28 October 2011]

\section{ABSTRACT}

The type specimen of peisleyite has been reinvestigated by a combination of scanning electron microscopy, electron probe microanalysis (EPMA) and synchrotron powder X-ray diffraction. Morphological investigation showed that mats of peisleyite crystals, individually $<3 \mu \mathrm{m}$ across, are intergrown with wavellite veinlets to form the white cryptocrystalline material that is typical of 'peisleyite'. New EPMA data (mean of 12 analyses) gave the empirical formula of peisleyite as $\left(\mathrm{Na}_{1.69} \mathrm{Ca}_{0.18}\right)_{\Sigma 1.87}\left(\mathrm{Al}_{9.04} \mathrm{Fe}_{0.03}\right)_{\Sigma 9.07}\left[\left(\mathrm{P}_{6.28} \mathrm{~S}_{1.38} \mathrm{Si}_{0.25}\right) \mathrm{O}_{4}\right]_{\Sigma 7.91}(\mathrm{OH})_{6.66} \cdot 27.73 \mathrm{H}_{2} \mathrm{O}$, or ideally $\mathrm{Na}_{2} \mathrm{Al}_{9}\left[(\mathrm{P}, \mathrm{S}) \mathrm{O}_{4}\right]_{8}(\mathrm{OH})_{6} \cdot 28 \mathrm{H}_{2} \mathrm{O}$. The associated wavellite was found to be F-rich. Synchrotron powder data were indexed and refined and gave the following unit cell: $P \overline{1}, a=9.280(19), b=11.976(19), c=$ 13.250(18) $\AA, \alpha=91.3(1), \beta=75.6(1), \gamma=67.67(1)^{\circ}, V=1308(5) \AA^{3}$ and $Z=4$. These data are significantly different to those reported in the original description of peisleyite.

KEYwords: peisleyite, wavellite, phosphate, sulphate, Toms phosphate quarry, South Australia, synchrotron.

\section{Introduction}

Peisleyite is a hydrated sodium aluminium phosphate-sulphate originally described by Pilkington et al. (1982) from Toms phosphate quarry, Kapunda, Mt Lofty Ranges, South

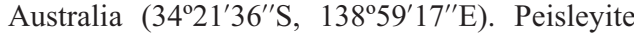
has only been found at Toms quarry as cryptocrystalline white masses up to several centimetres across (Fig. 1). These masses consist of tiny platelets, which are no more than a few $\mu \mathrm{m}$ in their maximum dimension. Frost et al. (2004, 2005) studied the thermal decomposition and Raman spectra of peisleyite, but no other studies have looked at peisleyite thus far. The aim of the current study is to shed more light on the complex chemistry of this rare and unusual secondary mineral. The study was conducted on type material from the collections of Museum Victoria (specimen M35630).
* E-mail: smills@museum.vic.gov.au

DOI: 10.1180/minmag.2011.075.6.2733

\section{Morphology}

In the original description of peisleyite, Pilkington et al. (1982) reported small veinlets of wavellite intermixed with the peisleyite, and noted that

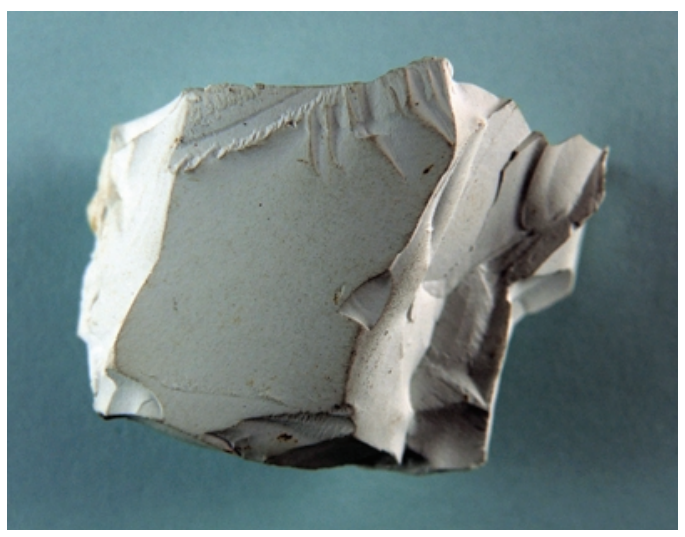

Fig. 1. The type specimen of peisleyite, a cryptocrystalline mass $\sim 30 \mathrm{~mm}$ across intergrown with wavellite. Museum Victoria collection, accession number M35630. 
these could easily be removed during sampling. Our examination of the type specimen showed that the veinlets of wavellite are more pervasive throughout the peisleyite, and that wavellite and peisleyite are finely intergrown on a $\mu \mathrm{m}$ scale. In general, the wavellite veinlets are about $20-100 \mu \mathrm{m}$ in width. Scanning electron microscope (SEM) images show that 'massive peisleyite' consists of zones of intergrown peisleyite crystals $(<3 \mu \mathrm{m}$ in size $)$ forming mats (Fig. 2) intermixed with zones of massive wavellite with no distinct crystal faces (Fig. 3).

\section{Chemical analyses}

\section{Peisleyite}

Twelve chemical analyses were carried out on a JEOL8200 electron microprobe (operating in WDS mode at $15 \mathrm{kV}, 10 \mathrm{nA}$ with a $20 \mu \mathrm{m}$ beam diameter) at the Division of Geological and Planetary Sciences, California Institute of Technology (Table 1). The standards used were: anorthite for $\mathrm{Si}, \mathrm{Al}$ and $\mathrm{Ca}$; fayalite for $\mathrm{Fe}$; forsterite for $\mathrm{Mg}$; albite for $\mathrm{Na}$; microcline for $\mathrm{K}$; fluorapatite for P; anhydrite for S; and phlogopite for F. Initially a $1 \mu \mathrm{m}$ focused beam was used to analyse a single peisleyite platelet, however, the platelet was destroyed by the electron beam in a matter of seconds. Therefore, a defocused beam was used to avoid significant damage, to which peisleyite is particular prone due to its high water content. Consistent results were obtained using a defocused beam, although the totals are slightly low due to the openness and small crystal size, indicating that a small amount of epoxy was present in the volume excited by the beam. The $\mathrm{H}_{2} \mathrm{O}$ content (31.67 wt.\%) was taken from the thermal analysis data of Frost et al. (2004). The senior author (SM) was involved in this study, and was able to sample and evaluate the peisleyite before the analyses. Although we cannot discount the possibility that a small amount of wavellite was present in the sample, SEM analyses indicated the sample studied was pure. Therefore, we are confident that the slightly low totals presented in Table 1 are not due to missing water.

The empirical formula for peisleyite (based on 66 oxygen atoms) is $\left(\mathrm{Na}_{1.69} \mathrm{Ca}_{0.18}\right)_{\Sigma 1.87}$ $\left(\mathrm{Al}_{9.04} \mathrm{Fe}_{0.03}\right)_{\Sigma 9.07}\left[\left(\mathrm{P}_{6.28} \mathrm{~S}_{1.38} \mathrm{Si}_{0.25}\right) \mathrm{O}_{4}\right]_{\Sigma 7.91}$ $(\mathrm{OH})_{6.66} .27 .73 \mathrm{H}_{2} \mathrm{O}$, or ideally $\mathrm{Na}_{2} \mathrm{Al}_{9}\left[(\mathrm{P}, \mathrm{S}) \mathrm{O}_{4}\right]_{8}(\mathrm{OH})_{6} \cdot 28 \mathrm{H}_{2} \mathrm{O}$. The original wet chemical analyses of Pilkington et al. (1982) produce a formula based on 66 oxygen atoms $\left(\mathrm{Na}_{2.21} \mathrm{Ca}_{0.23}\right)_{\Sigma 2.44}\left(\mathrm{Al}_{12.30} \mathrm{Fe}_{0.04}\right)_{\Sigma 12.34}$ $\left[\left(\mathrm{P}_{7.34} \mathrm{~S}_{1.64} \mathrm{Si}_{0.25}\right) \mathrm{O}_{4}\right]_{\Sigma 9.23}(\mathrm{OH})_{13.39} \cdot 15.7 \mathrm{H}_{2} \mathrm{O}$, which is considerably different to that generated from the data presented here. However, wet chemical analyses, because they are conducted on relatively large samples, are commonly compromised by impurity phases and in this case, we suspect contamination from the associated wavellite veins and/or one other unknown mineral (also noted in the X-ray data).

\section{Wavellite}

An average of six quantitative analyses of the wavellite veinlets (Table 1) gives the following

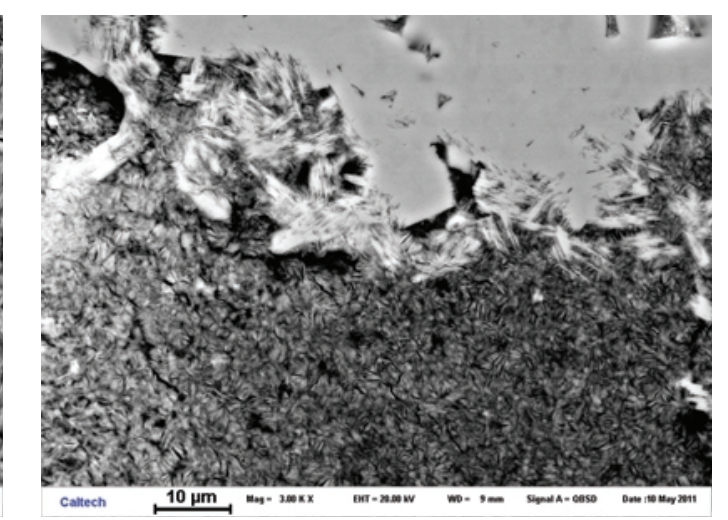

FIG. 3. Scanning electron microscope image of intergrown regions of peisleyite (mats, grey) and wavellite (compact, light). The field of view is $\sim 50 \mu \mathrm{m}$ across.
FIG. 2. Scanning electron microscope image of inter- grown crystals of peisleyite in a close-knitted mat. The
field of view is $\sim 20 \mu \mathrm{m}$ across.

grown crystals of peisleyite in a close-knitted
field of view is $\sim 20 \mu \mathrm{m}$ across.

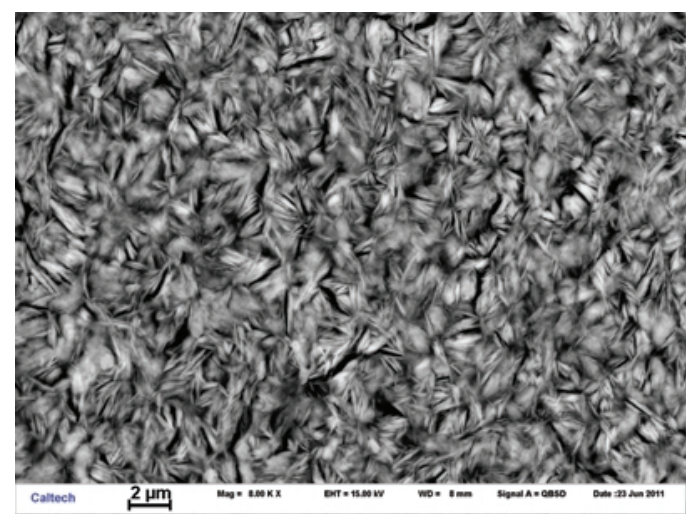


TABLE 1. Chemical analyses of peisleyite and wavellite.

\begin{tabular}{|c|c|c|c|c|c|c|c|c|}
\hline & Peisleyite* & sd & $\begin{array}{l}\text { a.p.f.u. } \\
(\mathrm{O}=66)\end{array}$ & $\begin{array}{c}\text { Original } \\
\text { peisleyite }^{\dagger}\end{array}$ & $\begin{array}{c}\text { a.p.f.u. } \\
(\mathrm{S}+\mathrm{P}+\mathrm{Si}=12)\end{array}$ & Wavellite* & sd & $\begin{array}{c}\text { a.p.f.u. } \\
(\mathrm{O}=17.5)\end{array}$ \\
\hline $\mathrm{Na}_{2} \mathrm{O}$ & 2.97 & 0.55 & 1.69 & 3.83 & 2.88 & 0.00 & 0.00 & \\
\hline $\mathrm{K}_{2} \mathrm{O}$ & 0.01 & 0.01 & & 0.03 & 0.01 & 0.00 & 0.00 & \\
\hline $\mathrm{CaO}$ & 0.56 & 0.09 & 0.18 & 0.71 & 0.30 & 0.00 & 0.00 & \\
\hline $\mathrm{MgO}$ & 0.00 & 0.00 & & 0.02 & 0.01 & 0.25 & 0.07 & 0.02 \\
\hline $\mathrm{Fe}_{2} \mathrm{O}_{3}$ & 0.13 & 0.03 & 0.03 & 0.17 & 0.05 & 0.29 & 0.05 & 0.02 \\
\hline $\mathrm{Al}_{2} \mathrm{O}_{3}$ & 26.06 & 1.32 & 9.01 & 35.03 & 16.00 & 32.85 & 0.44 & 2.83 \\
\hline $\mathrm{P}_{2} \mathrm{O}_{5}$ & 25.20 & 2.16 & 6.26 & 29.10 & 9.55 & 32.96 & 0.34 & 2.04 \\
\hline $\mathrm{SiO}_{2}$ & 0.85 & 0.14 & 0.25 & 0.83 & 0.32 & 0.00 & 0.00 & \\
\hline $\mathrm{SO}_{3}$ & 6.24 & 0.65 & 1.37 & 7.33 & 2.13 & 0.00 & 0.00 & \\
\hline $\mathrm{F}$ & 0.00 & 0.00 & & - & - & 3.34 & 0.18 & 0.77 \\
\hline Oxide & 62.03 & 4.25 & & & & 69.69 & 0.40 & \\
\hline $\begin{array}{l}\mathrm{H}_{2} \mathrm{O} \\
-\mathrm{F}=\mathrm{O}\end{array}$ & $\begin{array}{r}31.67 \\
0.00\end{array}$ & & 74.31 & 22.54 & 58.25 & $\begin{array}{r}31.72 \\
-1.41\end{array}$ & & 15.46 \\
\hline Total & 93.69 & & & 99.60 & & 100.00 & & \\
\hline
\end{tabular}

Note: a.p.f.u. is atoms per formula unit, based on 66 oxygen atoms in the new peisleyite data and on 12 sulphur plus phosphorus plus silicon atoms in the data from Pilkington et al. (1982); the wavellite formula in based on 17.5 oxygen atoms per formula unit; sd is the standard deviation;

* mean of 12 EPMA analyses;

$\dagger$ mean of 2 wet chemical analyses from Pilkington et al. (1982);

* mean of 6 EPMA analyses.

empirical formula (based on 17.5 oxygen atoms): $\left(\mathrm{A}_{2} .8{ }_{3} \mathrm{Fe}_{0.02} \mathrm{Mg}_{0.02}\right)_{\Sigma 2.87}\left(\mathrm{PO}_{4}\right)_{2.04}$ $\mathrm{F}_{0.77}(\mathrm{OH})_{1.70} \cdot 6.88 \mathrm{H}_{2} \mathrm{O}$. This has a slightly higher water content than the ideal wavellite formula, probably due to minor damage in the beam. Interestingly, the wavellite contains significant $\mathrm{F}$, but not enough for it to be considered as a separate species.

\section{X-ray diffraction}

A synchrotron powder X-ray diffraction (PXRD) pattern for peisleyite was obtained using the Australian high-resolution powder diffractometer (Big Diff) at the Photon Factory, Tsukuba, Japan. The mineral was finely ground and packed into a $1 \mathrm{~mm}$ Lindemann capillary. Partial diffraction rings were collected on image plates located $573 \mathrm{~mm}$ from the axially spinning sample. An X-ray wavelength of $0.8000 \AA$ was used. Calibration was via a $\mathrm{Si}$ standard (refined parameter $a=5.431(1) \AA$ ). A second standard, ground synthetic $\mathrm{Y}_{2} \mathrm{O}_{3}$ (Aldrich, 99.999\%), which has a refined cell of $a=10.6018(7) \AA$ and $V=$ 1191.62(7) $\AA^{3}$, in $I a \overline{3}$ was also added (see Mills et al., 2011). The angular range of the data is $3-123^{\circ}$ in steps of $\sim 0.01^{\circ} 2 \theta$.

Peaks attributed to wavellite were discarded and the remaining peaks corresponding to peisleyite were indexed using the Crysfire suite (Shirley, 2002). Several programs in the Crysfire suite returned an identical triclinic unit cell with $a \sim 9.3, b \sim 11.9, c \sim 13.2 \AA, \alpha \sim 91, \beta \sim 76, \gamma \sim 68^{\circ}$. This cell was refined in space group $P \overline{1}$ using Chekcell (Laugier and Bochu, 2004) which produced the following parameters: $a=$ 9.280(19), $b=11.976(19), c=13.250(18) \AA$, $\alpha=91.3(1), \beta=75.6(1), \gamma=67.67(1)^{\circ}, V=$ 1308(5) $\AA^{3}$ and $Z=4$. The indexed PXRD pattern is given in Table 2. It should be noted that this cell differs from the original peisleyite unit cell, which has $a=13.310(6), b=12.620(6), c=$ 23.15(1) $\AA, \beta=110.00(3), V=3654 \AA^{3}$ and $Z=2$; it occupies roughly one third of the volume. There are some similarities between the two cells as the $b$ and $c$ parameters in the new cell are similar in size to the $a$ and $b$ parameters in the old cell, although this may be a coincidence. The old cell can be discarded as several X-ray lines in the powder patter reported by Pilkington et al. (1982) 
were not observed in the synchrotron pattern (Table 2). It should be noted that neither the new cell nor the new chemistry corresponds to an analogue of a known mineral or synthetic phase.

\section{Density}

A small fragment of peisleyite (inspected in the SEM to confirm the absence of wavellite veins) was used to measure the density, by the sink-float method, in an aqueous solution of sodium polytungstate. The result, $2.20(5) \mathrm{g} \mathrm{cm}^{-3}$, compares well with the value of $2.23 \mathrm{~g} \mathrm{~cm}^{-3}$, which is calculated on the basis of the new EPMA data and new unit cell. Using these data (with the original optics) the Gladstone-Dale compatibility index (Mandarino, 1981), a measure of the quality of the data, is 0.030 , which is 'excellent'. In comparison, the measured density of $2.12 \mathrm{~g} \mathrm{~cm}^{-3}$, chemistry and unit-cell parameters reported by Pilkington et al. (1982) produce a Gladstone-Dale compatibility index of -0.060 , which is only 'fair'.

\section{Conclusions}

New analyses of the type specimen of peisleyite show that it is intimately mixed with F-rich wavellite on a $\mu \mathrm{m}$ scale, and that peisleyite is triclinic with the ideal formula

TABLE 2. X-ray powder diffraction data for peisleyite.

\begin{tabular}{|c|c|c|c|c|c|}
\hline \multirow{2}{*}{$\overline{d_{\mathrm{obs}}}$} & \multicolumn{2}{|c|}{ New synchrotron data } & \multirow[b]{2}{*}{$h k l$} & \multicolumn{2}{|c|}{ Pilkington et al. (1982) ${ }^{\dagger}$} \\
\hline & $I_{\mathrm{obs}}$ & $d_{\text {calc }}$ & & $d_{\mathrm{obs}}$ & $I_{\mathrm{obs}}$ \\
\hline 12.662 & 100 & 12.723 & 001 & 12.63 & 100 \\
\hline 10.985 & 63 & 10.982 & $0 \overline{1} 0$ & 10.85 & 15 \\
\hline 8.254 & 10 & 8.245 & 100 & 7.82 & 35 \\
\hline 8.021 & 20 & 8.012 & 101 & 7.59 & 30 \\
\hline 7.837 & 38 & 7.822 & 011 & 6.43 & 15 \\
\hline 7.678 & 35 & 7.681 & 111 & 6.32 & 10 \\
\hline 6.462 & 11 & 6.480 & $\overline{1} \overline{1} 1$ & 5.41 & 35 \\
\hline 6.330 & 4 & 6.361 & 002 & $5.23 *$ & 8 \\
\hline 5.459 & 29 & 5.491 & 020 & 4.98 & 8 \\
\hline 4.877 & 5 & 4.871 & $1 \overline{1} 2$ & $4.71 *$ & 10 \\
\hline 4.390 & 28 & 4.391 & 122 & $4.57^{*}$ & 8 \\
\hline 4.011 & 6 & 4.006 & 202 & $4.35^{*}$ & 20 \\
\hline 3.816 & 5 & 3.812 & $\overline{1} \overline{3} 1$ & $4.28^{*}$ & 10 \\
\hline 3.798 & 4 & 3.795 & 131 & $4.11 *$ & 15 \\
\hline 3.510 & 11 & 3.509 & 123 & 3.99 & 5 \\
\hline 3.476 & 13 & 3.480 & 203 & $3.92 *$ & 5 \\
\hline 3.393 & 9 & 3.390 & $\overline{1} \overline{3} 2$ & 3.79 & 5 \\
\hline 3.353 & 11 & 3.366 & 132 & 3.51 & 5 \\
\hline 3.315 & 4 & 3.323 & $\overline{1} \overline{2} 3$ & 3.47 & 12 \\
\hline 3.188 & 5 & 3.181 & 004 & 3.34 & 10 \\
\hline 2.990 & 12 & 2.986 & $\overline{1} \overline{4} 0$ & 3.29 & 5 \\
\hline 2.944 & 17 & 2.944 & $\overline{2} \overline{3} 2$ & 3.16 & 10 \\
\hline 2.874 & 18 & 2.873 & $\overline{2} \overline{4} 0$ & $3.11^{*}$ & 5 \\
\hline 2.844 & 10 & 2.843 & 331 & 2.93 & 10 \\
\hline 2.734 & 11 & 2.736 & $2 \overline{1} 4$ & 2.88 & 10 \\
\hline 2.661 & 8 & 2.661 & 142 & 2.72 & 10 \\
\hline 2.522 & 6 & 2.522 & 341 & 2.65 & 5 \\
\hline 2.106 & 5 & 2.104 & $\overline{2} 23$ & $2.61 *$ & 5 \\
\hline 2.058 & 5 & 2.059 & $\overline{3} 03$ & & \\
\hline 2.042 & 3 & 2.040 & $\overline{3} 43$ & & \\
\hline
\end{tabular}

\footnotetext{
${ }^{\dagger}$ The first four reflections are an average of diffractometer and Guinier film data $(\mathrm{Cu}-K \alpha)$, the remainder are measured from Guinier film data only.

* Reflections not found in the synchrotron data are assumed to be due to a contaminating phase.
} 
$\mathrm{Na}_{2} \mathrm{Al}_{9}\left[(\mathrm{P}, \mathrm{S}) \mathrm{O}_{4}\right]_{8}(\mathrm{OH})_{6} \cdot 28 \mathrm{H}_{2} \mathrm{O}$. Due to its high water content and instability under even a low intensity electron beam, further analyses that would enable complete crystal structure characterization (e.g. transmission electron microscopy) are impossible at this time. Until a second locality for peisleyite is discovered, or new methods become available, many of its fine details will remain a mystery, but it is certain that peisleyite represents a new and unique structure type for phosphate (arsenate) and sulphate minerals.

\section{Acknowledgements}

Referees Igor Pekov and Jiri Sejkora provided helpful comments on the manuscript and these are greatly appreciated. The collection of synchrotron data was undertaken at the Australian National Beamline Facility at the Photon Factory, Tsukuba, Japan, with support from the Australian Synchrotron Research Program, which is funded by the Commonwealth of Australia under the Major National Research Facilities Program. The SEM and EPMA analyses were carried out at the Caltech Geological and Planetary Sciences Division Analytical Facility, which is supported in part by NSF Grant EAR-0318518 and the NSF MRSEC Program under Grant DMR-00800065. John Bosworth is thanked for taking the photograph of the type specimen.

\section{References}

Frost, R.L., Mills, S.J. and Erickson, K.L. (2004) Thermal decomposition of peisleyite: a thermogravimetry and hot stage Raman spectroscopic study. Thermochimica Acta, 419, 109-114.

Frost, R.L., Mills, S.J. and Weier, M.L. (2005) Peisleyite, an unusual mixed anion mineral: a vibrational spectroscopic study. Spectrochimica Acta Part A: Molecular and Biomolecular Spectroscopy, 61, 177-184.

Laugier, J. and Bochu, B. (2004) Chekcell: Graphical powder indexing cell and space group assignment software. http://www.ccp14.ac.uk/tutorial/lmgp/.

Mandarino, J.A. (1981) The Gladstone-Dale relationship. IV. The compatibility concept and its application. The Canadian Mineralogist, 19, 441-450.

Mills, S.J., Kartashov, P.M., Ma, C., Rossman, G.R., Novgorodova, M.I., Kampf, A.R. and Raudsepp, M. (2011) Yttriaite-(Y): the natural occurrence of $\mathrm{Y}_{2} \mathrm{O}_{3}$ from the Bol'shaya Pol'ya river, Russian Federation. American Mineralogist, 96, 1166-1170.

Pilkington, E.S., Segnit, E.R. and Watts, J.A. (1982) Peisleyite, a new sodium aluminium sulphate phosphate. Mineralogical Magazine, 46, 449-452.

Shirley, R. (2002) The Crysfire 2002 System for Automatic Powder Indexing: User's Manual. The Lattice Press, 41 Guildford Park Avenue, Guildford, Surrey, UK. 
